\title{
Uroda i mądrość konstrukcji binarnej
}

\section{Mieczysław Dąbrowski, Dwa wątki, Dom Wydawniczy ELIPSA, Warszawa 2015, $324 \mathrm{~s}$.}

Trudno przecenić znaczenie akademickiego studium Mieczysława Dąbrowskiego na temat porównawczego czytania tekstów kultury oraz kwestii polsko-żydowskich, oferującego wykład, interpretację i przegląd szerokiego spectrum zjawisk literackich, kulturowych i społecznych w mistrzowski sposób poddanych refleksji heurystycznej w konstrukcji binarnej czy też podwójnej, dwuczłonowej. Tej dwoistości przyjdzie jeszcze się przyjrzeć, ale sygnalizuje ją tytuł $D w a$ wątki, z których część pierwsza nosi tytuł Lektury podwójne, a druga - Literatura polsko-żydowska. Noty wokół trudnego tematu.

Przedtem jednak warto dokonać charakterystyki recenzowanej publikacji. Stanowi ona interesujące, kompetentne i rzetelne opracowanie komparatystyczne, obejmujące szerokie pola problemowe i analizowane z zastosowaniem nowoczesnych ujęć badawczych na potrzeby wykładu kwestii ważnych i aktualnych. Każde ze studiów problemowych odsłania metodologiczne zaplecze, niejako zapraszając czytelnika do wspólnej intelektualnej przygody.

Trzy kwestie zwracają uwagę. Po pierwsze, recenzowana publikacja stanowi dopełnienie i praktyczny wykład znanego i świetnie przyjętego podręcznika akademickiego pt. Komparatystyka. Podręcznik akademicki (red. Mieczysław Dąbrowski, Warszawa 2011). Zawarte w omawianym tomie studia dają przykład zastosowań wyłożonych w podręczniku kwestii, metodologii i narzędzi. Po drugie, tom posiada dyskursywny charakter, co oznacza, że jest wykładem naukowym, rzetelnym, głębokim, ale prowadzonym ze swobodą, swadą i lekkością. Porusza kwestie trudne, czasami nawet bardzo bolesne, ale zachowuje takt, konieczny dystans i nie zmusza czytelnika do aprobaty autorskich racji, przedkładając prawidła 
dyskursu ponad perspektywę subiektywną. Oznacza to, że podręcznik posiada pewną właściwość ,interaktywną”: wiele oferując, wymaga także od czytelnika intelektualnego zaangażowania. Po trzecie wreszcie, studium Mieczysława Dąbrowskiego jako dzieło nowoczesne, żywe i pożyteczne, dowodzi znaczenia komparatystyki, której rola - jak można się spodziewać - będzie we współczesnym świecie ciągle wzrastała, choćby dlatego, że najważniejsi są sąsiedzi, a w świecie globalnym nawet najbardziej odległy mieszkaniec staje się sąsiadem. Studium Dąbrowskiego daje przykłady praktycznego zastosowania tej dyscypliny, opartej na realizacji szerokiego zakresu badań, specyficznych narzędziach i szczególnej perspektywie oglądu złożoności i zróżnicowania dzisiejszego świata, odpowiadającej zwrotowi kulturowemu, który każe zarzucić literaturocentryzm na rzecz szerokiego otwarcia na wszelkie praktyki kulturowe.

Recenzencki obowiązek wymaga zaprezentowania choćby głównych wątków problemowych omawianego tekstu.

Część I książki: Lektury podwójne obejmuje literaturę Warszawy, Gdańska, Śląska i Triestu. Teksty warszawskie (Miron Białoszewski) analizuje autor w kręgu inspiracji geokulturowych i lokalnych (Poznańska i Sielce jako linie/miejsca graniczne określały przestrzeń i warunki cywilizacyjne powojennej Warszawy). Literaturę gdańską (Günter Grass, Stefan Chwin i Paweł Huelle) interpretuje Dąbrowski w świetle postkolonializmu (jako model narracji, typ aksjologii i teorię), przy czym wprowadza bardzo istotne rozróżnienie pomiędzy tekstami pisanymi bez uwewnętrznionej świadomości postkolonialnej - pozostającymi na poziomie nagich faktów, których właściwe (lub „właściwe”, czyli intencjonalne, zideologizowane) rozumienie wytwarza się w drodze interpretacji często ex post - a tekstami, którym taka świadomość towarzyszy od momentu powstania. Śląsk Horsta Bienka to miejsce spotkania Słowiańszczyzny z germańskością, obszar strukturalnego mieszania się etnosów, ras, kultur, tradycji, języków, religii i obyczaju, który jest szczególnie wrażliwy na wielką politykę. Śląsk traktowany jest przez Bienka jako kraina z dawien dawna historycznie ukształtowana, jego mieszkańcy zaś - Ślązacy stanowią odrębny etnos. Tekst Triestu (Italo Svevo, Umberto Saba, Claudio Magris, Boris Pahor) to wszechstronne, szeroko sproblematyzowane studium, obejmujące historię, geografię, tradycję i współczesność miasta, ulice, kawiarnie i literaturę, wszystko to, co składa się na tzw. geografię 
humanistyczną, geopoetykę. Triest bywa określany, jak stwierdza autor, jednocześnie jako miasto północy i miasto południa (,z wyglądu Północ, ale z klimatu już Południe”, s. 67). Dąbrowski prowadzi dyskurs uwzględniający Angelo Arę i Claudio Magrisa, żywioły narodowości: włoskiej, niemieckiej (austriackiej), żydowskiej, słowiańskiej (słoweńskiej przede wszystkim), greckiej, nie licząc pomniejszych enklaw.

Erudycyjne i błyskotliwe analizy porównawcze realizuje autor w kręgu dwoistych zjawisk literackich i kulturowych. Czesław Miłosz i Claudio Magris jako autorzy parafrazy mitu o Orfeuszu i Eurydyce (w tle jest jeszcze Rainer Maria Rilke), Czesław Miłosz i Elias Canetti jako autobiograficzne świadectwa wielokulturowości (Ruszczuk Canettiego i Szetejnie Miłosza), „miejsca mitotwórcze” oraz naznaczone rytualizmem, patriarchalizmem, wyrazistą formą duchową, zamkniętością, skończonością tego świata (s. 98). Robert Musil i Joseph Roth to opozycja ironii i nostalgii, gdyż bohaterowie Musila mają poczucie, że żyją „,w epoce przejściowej”, oraz literacki obraz całości pewnego doświadczenia ludzkiego, uwikłanego w zdarzenia natury politycznej. Stanisław Różewicz (Śmierć w starych dekoracjach) i Tomasz Mann (Śmierć w Wenecji) to w refleksji Dąbrowskiego przykład paraleli komparatystycznej, która obejmuje opozycję Rzymu i Wenecji, bohatera uhonorowanego tytułem von i prostaczka, a także uwikłanie bohaterów w śmiertelny związek Erosa i Tanatosa.

Dwa przypadki kulturowego przekładu Owidiusza: Jacka Bocheńskiego, Nazo poeta i Christopha Ransmayra, Die letzte Welt oznaczają konstrukcje tekstów w myśl estetyki postmodernistycznej, o ile jednak Ransmayr w sensie ideowym przekłada Owidiuszowe Metamarfozy tak, by uzyskać efekt historiozoficzny i metafizyczny, odnoszący się do tragicznych doświadczeń XX wieku, o tyle Bocheński podąża w stronę upolitycznienia tekstu.

Relacje tekst - film analizuje autor na przykładzie powieści Pierścionek z końskiego włosia Aleksandra Ścibora-Rylskiego i filmu Pierścionek $z$ orłem $w$ koronie Andrzeja Wajdy, stwierdzając, że w powieści Ścibora-Rylskiego obecne jest „dążenie do de-konstrukcji romantycznego modelu postrzegania bohatera i samej rzeczywistości wojennej, w filmie Wajdy widać jego re-konstrukcję" (s. 179). Pisarz zmierzał w kierunku dekonstrukcji polskiego romantycznego wzorca i mitu - pisze autor - reżyser zaś do jego rekonstrukcji i rewitalizacji. 
Problemy tzw. piątego świata (krytyka e/migracyjna) analizuje Dąbrowski na przykładzie podwójnej emigracji Andrzeja Bobkowskiego i Gustawa Reglera. Główne kwestie poruszane przez Dąbrowskiego dotyczą podwójnej emigracji i przejścia od wygnaństwa do emigracji oraz sposobu i skali (auto)wykorzenienia obu pisarzy w tym procesie.

W drugiej części książki: Literatura polsko-żydowska. Noty wokót trudnego tematu Mieczysław Dąbrowski podejmuje kwestie zrazu podstawowe, definiując kategorie pisarza polskiego żydowskiego pochodzenia, pisarza żydowskiego polskiego pochodzenia i pisarza polsko-żydowskiego, a także wprowadza kategorię fantazmatu żydowskiego ukształtowanego w polskiej świadomości i kulturze, posiadającego naturę akceptująco-wykluczającą, miłosno-nienawistną, filo- $\mathrm{i}$ antysemicką zarazem. Narracja obejmuje, w myśl powyższych przytoczeń, zarówno doświadczenia konkretne, rzeczywiste, jak i wyobrażone, fantazyjne, wykreowane, zmyślone. Odwołania do kanonu literatury narodowej (Mickiewicz, Orzeszkowa, Reymont) w tym dyskursie tworzą głos polski (ujęcie przedmiotowe), głos żydowski (ujęcie podmiotowe) realizują Julian Stryjkowski, Henryk Grynberg, Adolf Rudnicki. Swoistą syntezą tych dwóch ujęć jest podmiot fantazmatu polsko-żydowskiego, który reprezentują Tadeusz Konwicki, Hanna Krall, Andrzej Kuśniewicz.

Przecięcie perspektywy socjologicznej i kulturowej, kwestie radykalizmu i fundamentalizmu narodowego i religijnego skontrastowanego z modelem koegzystencji pojawiają się w niezwykle interesującym i nowatorskim ujęciu w rozdziale pt. Rody polsko-żydowskie: dyskursywizacja tożsamości (Joanny Olczak-Ronikier, W ogrodzie pamięci, 2001; Krzysztofa Teodora Toeplitza, Rodzina Toeplitzów. Książa mojego ojca, 2004 oraz Stefana i Witolda Lederów, Czerwona nić, 2005).

Strategie pisarstwa poholocaustowego Mieczysław Dąbrowski analizuje niezwykle interesująco i rzetelnie na przykładzie twórczości Grynberga i Krall. Twórczość Hanny Krall rozpatruje - zgodnie z kwalifikacją Paula de Mana - jako realizację wzorca telling: „Pisarstwo Krall ma - w sensie estetycznym - charakter elegijno-melancholijny, zawarta jest w nim drobiazgowa rejestracja minionego życia polskich Żydów, zbrodniczej przeszłości, niegodnych i heroicznych zachowań” (s. 258).

Twórczość Henryka Grynberga określa kategoria showing, gdyż narracja nastawiona jest przede wszystkim na efekt ukazywania, prezentacji. 
„Holocaust w tym dyskursie - zauważa Dąbrowski - występuje jako obiekt, źródłem tej mowy jest liryka, techniką prezentacji - dramatyzacja, a teleologią - performatywność” (s. 253) (Richard Schechner). „Pisarstwo Grynberga wywoływało i wywołuje nadal rozmaite napięcia na styku polskiej i żydowskiej świadomości, niekiedy uważa się go wręcz za skandalistę" (s. 254).

Rozdział pt. Żydowski barbarzyńca w polskim Edenie odsyła do ostatniego dwudziestolecia w zakresie przywracania polskiej pamięci kultury żydowskiej, ale tłem dla refleksji jest „nawiązanie do 20-lecia międzywojennego, gdzie dokonała się prawdziwa polaryzacja stanowisk polsko-żydowskich, czy może raczej polskich i żydowskich, i gdzie uderzający antysemityzm lat 30. zaciążył na zachowaniach Polaków w czasie Holocaustu” (s. 260).

Późna mowa wojenna to twórczość Mirona Białoszewskiego (Pamiętnik z powstania warszawskiego, 1970), Bogdana Wojdowskiego (Chleb rzucony umartym, 1971), Włodzimierza Odojewskiego (jego opus magnum, czyli powieść Zasypie wszystko, zawieje..., 1973). Utwory te pojawiają się w podobnym czasie, jest to przełom lat 60. i 70. XX wieku, a więc w ćwierć wieku po wojnie, i skłaniają autorów do odpowiedzi na pytania teoretyczne, dotyczące przede wszystkim sposobów mówienia o wojnie czy jej (nie)wyrażalności.

Studium zamyka rozdział poświęcony świadomości polskiej w przebudowie. Ten tekst łączy dwie perspektywy: społeczną i metodologiczną, a uwagi dotyczą trzech zjawisk istotnych po 1989 roku: stosunków polsko-żydowskich, homoseksualizmu i postkolonializmu.

Studium Mieczysława Dąbrowskiego pt. Dwa wątki to erudycyjny, ale wyłożony jasno i czytelnie przykład zastosowań współczesnej komparatystyki kulturowej, w pełni świadomej odejścia od wąsko pojmowanego przedmiotu badań, realizującej heurystykę interdyscyplinarną i interkulturową. Uznanie i respekt budzi szeroka perspektywa problemowa objęta refleksją badawczą (zagadnienia etniczne i narodowe, struktury i stosunki społeczne - głównie rodzinne, sposoby uprawiania polityki, ideologie, paradygmaty myślenia i wiedzy, obyczaje, rozumienie i odnoszenie się do ciała - a zwłaszcza płci i seksualności, formy religijności i stosunek do dogmatów religijnych, prawo, semiotyka kulturowa, auto- i heterostereotypy kulturowe itp.), podejmowana zawsze w świetle adekwatnych i rzetelnie realizowanych inspiracji metodologicznych. 
Studium w czytelny sposób ukazuje znaczenie współczesnej komparatystyki, która przynosi rewizję tradycyjnych dyskursów naukowych, wkracza na obszar filozofii kultury jako dziedziny badań interdyscyplinarnych oraz oferuje badanie paradygmatów, łączących literaturę z innymi dyskursami kultury. Trzeba także zauważyć, że Mieczysław Dąbrowski w obrębie literatury, kultury i myśli badawczej często wiąże perspektywę polską i niemiecką. Wprowadza tym samym nową i istotną wartość, gdyż współcześnie w polskiej humanistyce dominuje recepcja kultury i nauki brytyjskiej i amerykańskiej, z którymi kultura polska kontaktuje się w mniejszym stopniu.

Dwa wątki Mieczysława Dąbrowskiego to dzieło nowoczesne, prezentujące komparatystykę w jej współczesnych komplikacjach metodologicznych i interdyscyplinarnych, realizujące wzorzec humanistyki zaangażowanej. Badania porównawcze w tej publikacji nie sytuują się w opozycji do literaturoznawstwa narodowego, są jego koniecznym uzupełnieniem. Jeżeli literatura narodowa ma być zespołem treści i obrazów oddziałujących na wyobraźnię współczesnego odbiorcy, musi być konfrontowana w układzie synchronicznym: z podobnymi zjawiskami danej epoki i środowiska, a w układzie diachronicznym: ze współczesnymi sposobami odbioru tekstu, rozumieniem zjawisk i systemów kultury, z dzisiejszą wrażliwością; te zaś kształtują się nie tylko na narodowym podwórku, lecz również w świecie, mają charakter powszechny. 